\title{
Work activities as a resource for work organization design and for strategic decisions?
}

\author{
Sznelwar, L. I ${ }^{\mathrm{a}}$ and Hubault, $\mathrm{F}^{\mathrm{b}}$. \\ ${ }^{a}$ Department of Production Engineering of the Polytechnic School of the University of São Paulo, Brazil \\ laertesz@usp.br. \\ ${ }^{b}$ CEP-Ergonomie et Ecologie Humaine - University of Paris 1 Panthéon - Sorbonne - ATEMIS, France \\ cepergo@univ-paris1.fr.f.hubault@atemis-lir.com
}

\begin{abstract}
This paper proposes a discussion about the possibilities to link strategic decisions to working activities performed by workers. In that sense contributions from activities analysis could be considered in order to design and manage production.
\end{abstract}

Keywords: Working activities, Ergonomic Work Analysis, Strategic decisions, Organization Design

Should work activities conducted by different people in many different production systems be seen as a resource for the design of work organization and decision-making processes in different companies?

According to the assumptions of taylorism and fordism, work can and should be fixed in advance, it being the responsibility of the planners to define how best to perform it for the production objectives to be achieved. Among the paradigms of this model, which is still very prevalent, one should emphasize the importance of the linear production sequence, the idea of work simplification and control and, above all, the separation of men between those who plan the work and those who execute it.

Although these ideas were based on scientific assumptions that at the time were hegemonic and derived from positivism, many of them are outdated. Additionally, they have proved to be unsuitable, since right from the start they were based on false assumptions about human beings. In seeking production based on a proposed average human being, who is devoid of ideas, culture, history and desires, this proposal leads to an impasse, because its application in the real world means reifying individuals, by transforming them into mere production resources.
If on the one hand the representations of the human being were already profoundly unsuitable, the Taylor-Ford prerogatives were correlated with a relatively stable and sequential production process in which different aspects of the variability of the production, above all the emergence of events, should be ignored; everything that was different or that hindered the good progress of production should be opposed and, if possible, eliminated.

However, in some types of production this type of paradigm did not achieve the same success, even if it did have a great influence. Thus, among other elements, one should consider production in continuous process systems and the different types of services' industry.

The influence of this type of paradigm on the different approaches to work is very significant because it seeks to develop better working conditions, to "motivate" workers and to plan work equipment better. It reiterates the idea that there is a strong distinction between those who plan and those who execute the work. There is, therefore, a constant attempt to understand the cause-effect relations among the problems. In accordance with the prevalent viewpoint, in order to also motivate workers to work more and better, it is important to reward them individually and 
to offer them the prospect of professional advancement if they achieve and exceed the target results. Their involvement is unnecessary when it comes to improvements and new projects. After all, everything is hetero-determined and it is unnecessary to listen to them, involve them, share decisions with them and, above all, encourage their role as protagonists, as far as work and production are concerned. What is meant by protagonism here is the prospect of being the party that takes action and a person acknowledged to be capable of cooperating, given the prospect of thinking jointly in the search for best solutions.

Changes have occurred, in the sense of looking for new ways of organizing work and managing it. Other schools of thought have developed as from the mid20 th century and based on other paradigms. The belief that production and work systems cannot be absolutely controlled and, above all, that corporate needs themselves call for far more dynamic production systems (which can enable them to provide a greater range of products, deal appropriately with diversity, and respond to events) gave rise to other types of reflection and propositions regarding different production system concepts. Thus, assumptions such as a minimum level of prescription and less control over worker activities, coupled with greater levels of discretion, were introduced, largely in keeping with the so-called Sociotechnical Systems School.

Therefore, there was harmony with the development of other epistemologies, such as the systemic theories that include the prospect of Complexity. ${ }^{[1] ;[2] ;}$ [3]; [4] The possibility of introducing a vision according to which a grasp of the phenomena is more closely related to consideration of different variables, by trying to understand the relation between them and creating the notion of a network, of the dynamics of relationships, created a means of escaping from recording the manipulation of the world, in favor of a view according to which it was possible to take action in the world, while seeking to understand phenomena without isolating their variables in order to be able to manipulate them. Understanding that systems, as Edgar Morin proposes, would always tend towards disorder, due to an increase inherent in the existence of different types of entropy, and that from this disorder it would be possible to reach new levels of order, enables us to acquire a different grasp of what the different social systems are like, in this case the different companies and institutions. The Complexity prospect is, then, a means of looking for new ways of organizing production and work ${ }^{[5]}$. Starting with the assumption that these are dynamic systems and that they can only produce satisfactory results if there is constant intervention by the different players, i.e., that individuals act and that production depends on live work, we can consider that the activity of individuals is fundamental and that their understanding may be fundamental for the development of production systems.

Unlike other resources that are used and consumed, individuals are the only "resources" that can be developed. In fact, the words "human resources" is a euphemism since it puts humans on the same level as raw materials, machinery and installations. Coming from a predefined program, only the living individual, the human being, is capable of developing new strategies, of learning, of transmitting and of creating (autopoiesis ${ }^{[6]}$ ). Furthermore, because of his gregarious capacity, the worker is capable of cooperating and, through collective action, of trying to find solutions that individually would not be constructed or become feasible.

Another relevant aspect concerns the issue of how different workers deal with what is real, since what is considered for prescription and its results never corresponds to what is real. Skills and competences must be put to the test; after all, the intelligence needed to work is always required and individuals take risks, since they have to develop solutions for understanding matters, develop solutions for what is happening, while also improving their skills, since what is real in work puts to the tests the extent to which each person has a sound grasp of their previous knowledge. Working means constantly learning.

With regard to ergonomics, the idea of considering the activity of work as an analysis axis and as a parameter for transformation is one of the approaches that have been developed over the last 50 years. Analyzing the activity means understanding that the work of individuals is a synthesis of the characteristics of production, of its variability, of the way in which work is organized, of the relationships constructed in the company, of the content of the tasks, of the events, of the characteristics of the individuals and of the conditions of each one at a given point in time. In short, working is an act of synthesis and activities are undertaken within a certain context, where cultural, historical and ethical influences modulate them. 
Given the importance of individuals for production and for the project of solving problems, different schools of thought define ergonomics as a participatory approach ${ }^{[7] ;[8] ;[9] ;[10]}$. This is inherent to the point of view of those who use activity theories as a basis for understanding and transforming work. For those who mainly use an approach based on task analysis for the development of their actions in ergonomics, participation is also considered an important issue.

The differences between various approaches in ergonomics and a debate that is based on workers' activity as a resource for work organization and for strategic decisions should mutually enrich the perspectives of schools of thought in the field. ${ }^{[11]}$

First, if we examine the proposals of activity-based ergonomics, we must understand that worker activities are the main goal of the analysis. However, we cannot develop EWA (Ergonomic Work Analysis [12]; [13] $)$ without being familiar with the production situations. Talking about the activity without putting it into context is meaningless, since the different variables that modulate what people actually do are invisible unless there is prior knowledge of the task. Thus, understanding the variability of production, the business strategies, the management of the labor force work environment, which should be considered as various aspects of the universe of the task (objectives, productivity and quality criteria, the division of labor, organization of working time and production procedures, tools and workstations), is fundamental in order to understand the activities of people working in any production situation. In addition, the choices made by different social players that act and decide in the situation being analyzed should be understood in order to facilitate transformations.

In this sense, EWA should be considered as a multicenter approach that takes into account different variables, their expression and the links that weave together the different aspects of human work, thus enabling one to understand its complexity. The success in transforming and adapting work to human characteristics is linked to the ability of ergonomists and other social players involved in the process to understand that work activities are a synthesis. What is required of workers is the result of the expression of variables constituting the production situations. Ultimately, what workers actually do is the result of what is required, of their characteristics and of their conditions at the moment.
Work is a synthesis of all this. It is a compromise between the outside and the inside, where the worker is committed as a person, his body, and all his subjectivity. Work means thinking, reflecting, acting, and also what is not expressible, or even thinkable.

Another of the main reasons for understanding what happens in actual work is that there is always a gap between reality and what is determined for workers in their tasks. It is impossible to fit tasks and activities, since they do not mean the same thing; they are related to different ontological perspectives. What actually happens is never what was determined ahead of time, even if it is related. It is necessary to take account the events, and finally, to consider the dedication of people to achieve production targets. Another reason is that the possible transformations and their implementation are not simply the result of a decision-making process led as a neutral rationality. There are conflicts of interest, limitations and risks involved.

Among the great variety of examples that concern the activity it is important to note that the results of EWA almost invariably show a discrepancy between what is determined and what is real. To quote some examples:

1. Working in a control room in an oil refinery, following strictly what is determined in the supervisory system, i.e., merely monitoring that which was planned to function automatically may place the operations at risk. In analyzing the activities of these workers, particularly listening to worker explanations, it turns out that it is important for them to avoid the operation continuing in the prescribed manner, because the parameters provided for would lead to critical production levels, since they disregard the existence of backlogs in maintenance and the fact that the raw material is not of a consistent quality. So this work means keeping production from reaching critical levels.

2. A bus driver, in addition to driving the vehicle, must guarantee the safety of passengers, pedestrians and other vehicles and comply with his timetable. He also often provides other services to the population, such as giving information to those who ask for it and helping those who have some need. Additionally, to deal with the wide variety of 
events that can arise, such as acts of violence, it is necessary to develop strategies for avoiding confrontation, which can deteriorate the situation. Working with the unexpected and with events form part of his work, but it is not officially recognized, because in most cases orders and training ignore all of this.

3. Working with spreadsheet data analysis, as in back office tasks in banks, means facing problems related to the incorrect completion of the forms, which implies having to repeat some operation when the computerized system fails, as well as trying to solve issues that the software project did not cover.

4. Dealing with customers at a call center means struggling with orders that prevent the customer service staff from solving the issues they are faced with. How can a script be kept, how can operating procedures be fully respected and how can average call times be maintained if what the customer requires does not correspond to what has been determined regarding how the service is to be provided? There is also the work of decoding customer needs, since the way in which they express themselves and the questions they raise are not presented in the manner prescribed by the company orders.

5. When there is a risk of exposure to toxic substances, such as using pesticides in agriculture, the use of personal protective equipment may not be feasible, or even can worsen the risk. Developing strategies for avoiding exposure or even taking risks is part of the actual situation. The challenge for developing effective solutions remains open.

Those examples could illustrate a strategic issue relate to change decisions processes, since decisions are generally the result of a process in which work and what people think about their activity are not seen as major issues. Other social actors do not understand the work, because what people actually do is virtually unknown, or invisible. What appear are the results, the performance, linked to what was recommended in the task ontology. The process of doing, the activity of workers, is largely a mystery to the managers and engineers who have determined and designed tasks and work organization, and for those who proposed and conceived the equipment. The same could be said of other social actors.

Different approaches, such as that proposed by macro-ergonomics, are defined as having a top-down nature ${ }^{[14]}$. Most recommendations are based on knowledge about the characteristics of man and information about working conditions and an effort is done in order to also promote changes in the level or work organization and in companies strategies. Many good results are obtained by this approach. However, the question remains, though it is not taken into account, at least explicitly: is activity a fundamental project resource?

Full understanding of the activity is not central to planning and to design. A major issue for debate is whether it is necessary to seek more in-depth knowledge about human work and to try to understand what in fact happens, in order to improve our capacity to design, to plan and to manage work ${ }^{[15]}$.

Conceiving and planning production with workers' activity as the reference framework may seem paradoxical, since conceiving and planning are a way of predicting the future when there has not yet been any analyzable activity, meaning that activity characteristics cannot yet be incorporated into the project.

A main question in a project perspective should be related to the added value that is considered from working activities ${ }^{[16]}$. Material and immaterial issues should be considered as results of work and production ${ }^{[17]}$. This is certainly related to all kinds of jobs but is even more important when it's known that most part of the work in not visible and not recognized as being a important part for the results of the companies ${ }^{[18] ;[19]}$; that's one of the reasons that the mainly parameters of evaluative process of working doesn't fit to reality ${ }^{[20]}$.

However, experience in various situations in which there is an analysis of work activities in reference situations shows that it is both feasible and desirable ${ }^{[21] ;[22]}$. Moreover, it is very important that a large variety of types of simulation be carried out, based on reference situations, to provide a better understanding of what might happen. Carrying out trial experiments via electronic simulations has proved to be useful. 
Even if one uses this type of tool to get a good idea of what people might do in a future situation, of the difficulties they will face and of the possible solutions, it is impossible to predict everything. The reality will always be different from the plan; no project is carried out as planned; there are always adjustments to be made; and invariably events materialize that require modifying the system. Therefore, planning means, above all, involving the players, particularly those who will be directly involved with production per se, so that with their prior experience in the profession, they can contribute significantly to project success.

New trends in ergonomics are related to how improve human activity ${ }^{[23]}$, so it's possible to contribute to develop many different company strategies, add to health and safety questions, strategic business objectives ${ }^{[24]}$. In order to achieve different ways of developing projects, design steps should integrate an analysis of the existing situation by observations and interviews about work tasks, problems de users experiences and wishes they might have for the new situation. For that it'd important in order to bring ergonomics to engineering projects to involve user participation in the process to design the system ${ }^{[25]}$. In that perspective, link between the ways that we consider the economic issues and health related to work should be also analyzed, since subjects' engagements, social values and managers' points of view should be taken into account in order to prevent degradation in working situations ${ }^{[26]}$.

As in ergonomics, we are always dealing with people, with system dynamics meaning continuous change ${ }^{[27]}$, one of our main challenges should be to put in discussion its strategic issues in order to afford conditions for people to achieve themselves as subjects and to organizations to achieve their goals, always remembering that organizations are constituted by people with different interest, points or view and experiences.

There are still many problems related to working conditions and the promise that technology should liberate humans from dealing with tasks that are time consuming, difficult, subject to error has not been achieved ${ }^{[28]}$. There are still people dealing with unsafe and meaningless jobs, work should be considered as a central human activity that can afford conditions for people to look for self-realization ${ }^{[29] ; ~[30] . ~}$ In that way, work should be considered as a special locus to improve trust within people ${ }^{[31]}$, since cooperation is an important issue to achieve personal and collective goals.

Consequently, institutional means should be established within companies in which project activities are conducted. In that perspective, setting up committees to conduct project activities is an important step. Conducting a project means bearing in mind that there will be a confrontation of ideas, as the representations that each party has about what is intended is bound to be different. Thus, reaching decisions that incorporate different points of view is a major challenge.

\section{References}

[1] Morin, E., Ciência com consciência. 2.ed. Rio de Janeiro: Bertrand Brasil, 1998.

[2] Morin, E. and Le Moigne, J.L., A inteligência da complexidade. 2nd ed. São Paulo: Cortez, 2000.

[3] Montedo, U. B.; Sznelwar, L. I. The tacit relationship between ergonomic work analysis and the theory of complexity. In: 17th World Congress on Ergonomics - IEA 2009, 2009, Beijing.

[4] Dudziak, E.; Sznelwar L.I. and Plonski, G. A., Learning organizations and the paradigm of complexity: Work design approach in Carayon, P., Robertson, M., Kleiner, B. and. Hoonakker P.L.T (eds) Human Factors In Organisational Design and Management - VIII, IEA Press, Santa Monica, 2005, 335-340.

[5] Carayon, P., Human factors of complex sociotechnical systems, Applied Ergonomics 37 (2006) 525-535.

[6] Maturana, H. \& Varela, F. De maquinas y seres vivos: autopoiesis, la organización de lo vivo. Santiago: Editorial Universitaria, 1994.

[7] Wilson, J., Participation and its role in human factors, In Carayon, P., Robertson, M., Kleiner, B. and Hoonakker, P. L. T. (eds.) Human Factors in Organizational Design and Management - VIII, IEA Press, Santa Monica, 2005, p. 53-62

[8] Kogi, K., Participatory methods effective for ergonomic workplace improvement, Applied Ergonomics, 37 (2006) 547-554.

[9] Vink, P., Koningsveld, E. A. P. and Molenbroek. J. F., Positive outcomes of participatory ergonomics in terms of greater comfort and higher productivity. Applied Ergonomics 37 (2006) 537-546.

[10] Imada, A. S. The value of participation in ergonomics in Meeting Diversity in Ergonomics. Pikaar, Koningsveld and Settels (eds), 2007, pp 91-98.

[11] Hendrick, H.W. Macroergonomic analysis of structure, anthropotechnology, and modification of three classical research methods for macroergonomic application in Pikaar, R. N. \& Koningsveld, E.A.P. (ed) Meeting Diversity in Ergonomics, Proceedings of the IEA2006 Congress, July 2006, Maastricht, Netherlands.

[12] Guerin, F.; Laville, A.; Daniellou; F. Durraffourg; J. Kerguelen, A. Compreender o trabalho para transformá-lo. Edgard Blucher. São Paulo, 2001. 
[13] Wisner, A. Questões epistemológicas em ergonomia e em análise do trabalho in Daniellou, F. A ergonomia em busca de seus princípios, São Paulo, Editora Edgard Blücher, 2004 pp. 29-56

[14] Hendrick, H. W., ODAM and macroergonomics 20 years later: You've come a long way baby! In Carayon, P., Robertson, M., Kleiner, B. and Hoonakker, P. L. T. (eds.) Human Factors in Organizational Design and Management - VIII, IEA Press, Santa Monica, 2005, p. 25-34.

[15] Béguin, P., Taking activity into account during the design process in Pikaar, R. N. \& Koningsveld, E.A.P. (ed) Meeting Diversity in Ergonomics, Proceedings of the IEA2006 Congress, July 2006, Maastricht, Netherlands.

[16] Hubault, F. Le travail vaut par la manière dont on en use Contribution de l'ergonomie à la gestion des ressources humaines in Allouche, J. (coord.), Encyclopédie des ressources humaines, Paris, Vuibert, 2003

[17] Du Tertre, C. Bancos e Produtividade: Entre dinâmica industrial e dinâmica serviçal in Sznelwar, L.I. (org) Saúde dos Bancários, São Paulo, Publisher, 2011, pp. 64-82.

[18] Zarifian, P. Valeur de service et compétence, in Relation de service: regards croisés, Cahiers du genre, $\mathrm{n}^{\circ} 28,71-96$, Paris, L'Harmattan, 2000.

[19] Hubault, F. Le travail dans la gestion: tensions et contradictions In Beaujoulin-Bellet, R.; Louart, P. et Parlier, M. (coords) Le travail, un défi pour la GRH, Editions ANACT, 2008, pp. 22-40

[20] Dejours, C., L'évalutaion du travail à l'épreuve du reel, INRA Editions, Paris, 2003.

[21] Daniellou, F., The French ergonomists' approach to work activity: cross-influences of field intervention and conceptual models. Theoretical Issues in Ergonomics Science, Vol. 6, $\mathrm{n}^{\circ}$ 5, September 2005, 409-427.

[22] Daniellou, F., Simulating future work activity is not only a way of improving workstation design in Pikaar, R. N. \&
Koningsveld, E.A.P. (ed) Meeting Diversity in Ergonomics, Proceedings of the IEA2006 Congress, July 2006, Maastricht, Netherlands.

[23] Konigsveld. E.A.P.; Settels, P.J.M.; Pikaar, R.N. Meeting Diversity in ergonomics in Meeting Diversity in Ergonomics. Pikaar, Koningsveld and Settels (eds), 2007, pp 3-12.

[24] Dul, J. and Neuman, W.P. Strategic Business Value of Ergonomics in Meeting Diversity in Ergonomics. Pikaar, Koningsveld and Settels (eds), 2007, pp 17-27.

[25] Pikaar, R.N. in in Meeting Diversity in Ergonomics (2007). Pikaar, Koningsveld and Settels (eds), 2007, pp 29-51.

[26] Hubault, F. Os desafios relacionados à mobilização da subjetividade na relação de serviço Sznelwar, L.I. (org) Saúde dos bancários, São Paulo, Publisher, 2011, pp. 125-

[27] \$\&llelwar, L.I. Ergonomics and Work - Different approaches and challenges for the future in Meeting Diversity in Ergonomics (2007). Pikaar, Koningsveld and Settels (eds), 2007, pp 111-127.

[28] Boff, K. F., Revolutions and shifting paradigms in human factors and ergonomics, Applied Ergonomics, 37 (2006), 391-399.

[29] Dejours, C. Sofrimento e prazer no trabalho: A abordagem pela psicopatologia do trabalho. In: Lancman S, Sznelwar LI, organizadores. Christophe Dejours: da psicopatologia à psicodinâmica do trabalho. Brasília, Rio de Janeiro: Paralelo15/FIOCRUZ, p. 141-156, 2004.

[30] Hubault, F. Do que a ergonomia pode fazer a análise? in Daniellou, F., (coord.) A ergonomia em busca de seus princípios: debates epistemológicos, Edgard Blücher, São Paulo, 2004, p. 105-140.

[31] Dejours, C. \& Gernet, I. Trabalho, subjetividade e confiança in Sznelwar, L.I. (org) Saúde dos Bancários, São Paulo, Publisher, 2011, pp. 33-43. 